\title{
SEISMIC HAZARD ASSESSMENT OF UTTAR PRADESH LOCAL AND ACTIVE SEISMIC GAPS
}

\author{
Aayush Kumar \\ M.Tech, Department of Civil Engineering, \\ Madan Mohan Malaviya University of Technology, \\ Gorakhpur, Uttar Pradesh, India
}

\begin{abstract}
The Himalayas are the one of the most active seismic regions over in wide world. From where some of the devastating earthquake were originated; Bihar Nepal 1803, shilling 1897, Kangra 1905, Bihar Nepal 1934, Assam 1950, Sikkim 2011, Nepal Earthquake 2015 and last earthquake in Uttar Pradesh was October $18^{\text {th }} 2007$ in Gautam Buddha Nagar. Many of the research Analyser highlighted the central Seismic Gap based on the stress accumulation in the central region of the Himalaya, The regions which were situated adjacent to the active Himalayan regions having large possibility of seismic hazard. In this study, there is an assessment of spectral acceleration of Uttar Pradesh which were based upon the Probabilistic Seismic Hazard Analysis (PSHA). In past few Decades the population of the Uttar Pradesh is drastically increased is Approximately 16,61,98000 According to 2001 census. The comprehensive earthquake catalogue were compiled from various sources for region $23^{\circ} 52^{\prime} \mathrm{N}$ and $30^{\circ}$ 25 ' $N$ latitudes and $77^{\circ} .3^{\prime}$ and $84^{\circ} .39^{\prime} \mathrm{E}$ longitude that comprises the historic and prehistoric events. The seismic parameter has been estimated with the use of past data of control regions A seismic hazard map of Uttar Pradesh has been developed considering the region-specific seismotectonic parameters with a radius of $500 \mathrm{~km}$ by probabilistic approaches. The updated maximum probable earthquake magnitude (M max) for each seismic sources has been done by considering the regional rupture characteristic method and compared with the maximum magnitude observed. (Mobs max), Mobs $\max +0.5$ and Kijo Method. The best suitable Ground motion prediction equations (GMPE) were selected from 27 applicable GMPE's based on the 'Efficacy Test'. Wherever, Maximum expected magnitude (Mmax) low seismicity area like Uttar Pradesh based on Gutenberg-Richter Relationship. The recurrence relationship has been obtained using Guttenberg-Richter (G-R) relationship. The probabilistic seismic hazard analysis were then carried out considering well known seismogenic sources of Uttar Pradesh. The result of above investigation presented In the form of Peak Ground Acceleration 'PGA' and response Spectra.
\end{abstract}

Key Words: Seismic hazard, Probabilistic Seismic Hazard Analysis (PSHA), Seismotectonics, Response Spectrum.

\section{INTRODUCTION}

India is currently penetrating into Asia at a rate of approximately $45 \mathrm{~mm}$ /year and rotating slowly anticlockwise. Because of this translation and rotation result in left-lateral transformation slip in Baluchistan at the rate of $42 \mathrm{~mm} /$ year and right lateral slip relative to Asia in the Indo-Burman ranges at $55 \mathrm{~mm} /$ year. Deformation with the Tibet to approximately $18 \mathrm{~mm} /$ year, and because Tibet is extending east-west, convergence across the Himalaya is approximately normal to the arc. Arc normal convergence across the Himalaya results in the development of potential slip available to drive large thrust earthquakes beneath the Himalaya at roughly $1.8 \mathrm{~m} /$ century. The Indian Sub-continent has already experienced destructive earthquakes. The one main reason for high frequency and intensity of earthquake is Indian plate driving into Asia at a rate of approximately $47 \mathrm{~mm} /$ year. Uttar Pradesh is located at very close boundary that makes it vulnerable. Most of the state of Uttar Pradesh lies in the Gangetic Plain and has a population of 16,61,98,000 according to 2001 census and has an area of 240,928 sq. $\mathrm{km}$. The State has population density of 690 per sq. km. (as against the national average of 312). Uttar Pradesh is bounded by Nepal and Uttarakhand (A part of U.P separated on 09 November 2000) on the North, Himachal Pradesh on the North West, Haryana on the west and Rajasthan on the south west, Madhya Pradesh on the south and south- west, and Bihar on the east and Jharkhand on the south east. Situated between $23^{\circ} 52^{\prime} \mathrm{N}$ and $30^{\circ} 25^{\prime} \mathrm{N}$ latitudes and $77^{\circ} 3^{\prime}$ and $84^{\circ} 39^{\prime} \mathrm{E}$ longitudes, this is the fourth largest state in the country.

Uttar Pradesh can be divided into two distinct hypsographical regions:

1. The Gangetic plain

2. The Vindya hills and plateau in the south

Geologically this region is a fore-deep, a downwarp of the Himalayan foreland, of variable depth, converted into flat plains by long-vigorous sedimentation. Earthquakes have occurred in mostly all parts of Uttar Pradesh. Major earthquakes in the neighboring states of New Delhi, 


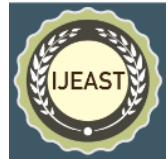

Uttarakhand, Bihar and from across the Indo-Nepal border have also shaken many parts of Uttar Pradesh. There is a need to proceed from hazard assessment to vulnerability analysis and ultimately generation of earthquake risk maps/figures.

\subsection{Vulnerability Assessment of the States}

Indian Situation Facts about Earthquakes in India

A list of some of the significant earthquakes in India and their locations are given below:-

Table-1.1 Significant Earthquake in India

\begin{tabular}{|c|c|c|}
\hline Date & Epicenter & Magnitude \\
\hline 1819 June 16 & Kutch, Gujarat & 8.0 \\
\hline 1869 Jan 10 & Near Cachar & 7.5 \\
\hline 1885 May 30 & Sopore, J\&K & 7.0 \\
\hline 1897 June 12 & Shillong Plateau & 8.7 \\
\hline 1905 April 4 & Kangra, H.P & 8.0 \\
\hline 1918 July 8 & Assam & 7.6 \\
\hline 1930 July 2 & Dhubri, Assam & 7.1 \\
\hline 1934 Jan 15 & Bihar Nepal & 8.3 \\
\hline 1941 June 26 & Andaman Islands & 8.1 \\
\hline 1943 Oct 23 & Assam & 7.2 \\
\hline 1950 Aug 15 & AP-China Border & 8.5 \\
\hline 1957 Dec 10 & Koyna, Maharashtra & 6.5 \\
\hline 1958 July 21 & Anjar, Gujarat & 7.0 \\
\hline 1975 Jan 19 & Kinnaur, H.P & 6.2 \\
\hline 1988 Aug 21 & Bihar-Nepal Border & 6.4 \\
\hline 1991 Oct. 20 & Uttarkashi & 6.6 \\
\hline 1993 Sept. 30 & Latur- & 6.3 \\
\hline 1997 May 22 & Jabalpur, MP & 6.0 \\
\hline 1999 March 29 & Chamoli, U.K & 6.8 \\
\hline 2001 Jan 26 & Bhuj, Gujarat & 7.9 \\
\hline 2004 Dec. 26 & West Coast of northern & 9.0 \\
\hline 2005 Oct. 08 & Muzaffarabad & 7.6 \\
\hline & & \\
\hline
\end{tabular}

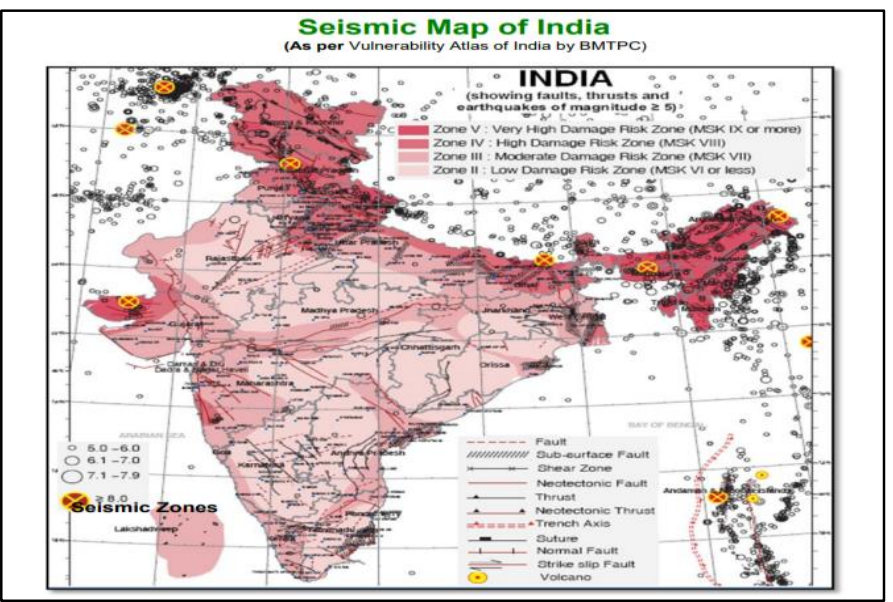

Figure 1.1 Seismic Map of India (As per Vulnerability Atlas of India by BMTPC)

\subsection{State wise Seismic Zonation Table 1.2}

\begin{tabular}{|l|l|l|}
\hline \multicolumn{1}{|c|}{ STATE \& U.Ts } & \multicolumn{1}{c|}{ INTENSITY } & SEISMIC ZONE \\
\hline $\begin{array}{l}\text { Andaman \& Nicobar } \\
\text { Islands }\end{array}$ & MSK IX or more & Zone V \\
\hline Arunachal Pradesh & MSK IX or more & Zone V \\
\hline Assam & MSK IX or more & Zone V \\
\hline Bihar & MSK V to IX & Zone V \\
\hline
\end{tabular}

\begin{tabular}{|l|l|l|}
\hline Gujarat & MSK VI to IX & Zone II, III \& V \\
\hline Himachal Pradesh & MSK VIII to IX & Zone IV \& V \\
\hline Jammu \& Kashmir & MSK VIII to IX & Zone IV \& V \\
\hline Manipur & MSK IX or more & Zone V \\
\hline Meghalaya & MSK IX or more & Zone V \\
\hline Mizoram & MSK IX or more & Zone V \\
\hline Nagaland & MSK IX or more & Zone V \\
\hline Tripura & MSK IX or more & Zone V \\
\hline Uttar Pradesh & MSK V to IX & Zone II, III,IV,V \\
\hline West Bengal & MSK VI to IX & Zone III, IV \& V \\
\hline Chandigarh & MSK VIII & Zone IV \\
\hline Delhi & MSK VIII & Zone IV \\
\hline Haryana & MSK VI to VIII & Zone II, III \& IV \\
\hline Maharashtra & MSK V to VIII & Zone II, III \& IV \\
\hline Punjab & MSK VI to VIII & Zone II, III \& IV \\
\hline Rajasthan & MSK V to VIII & Zone II, III \& IV \\
\hline Sikkim & MSK VIII & Zone IV \\
\hline Andhra Pradesh & MSK V to VII & Zone II \& III \\
\hline Dadra \& Nagar & Haveli MSK VII & Zone III \\
\hline Daman \& Diu & MSK VII & Zone III \\
\hline Goa & MSK VI to VII & Zone II \& III \\
\hline Karnataka & MSK V to VII & Zone II \& III \\
\hline Kerala & MSK VI to VII & Zone II \& III \\
\hline Lakshadweep & MSK VII & Zone III \\
\hline Madhya Pradesh & MSK V to VII & Zone II \& III \\
\hline Orissa & MSK V to VII & Zone II \& III \\
\hline Pondicherry & MSK VI to VII & Zone II \& III \\
\hline Tamil Nadu & MSK V to VII & Zone II \& III \\
\hline Note-In the & II \\
\hline
\end{tabular}

Note-In the revision of the seismic zones in year 2000, the seismic Zone I has been merged in Zone II by BIS Seismic Zoning Committee, hence there are now four zones only number II, III, IV \& V.

\subsection{EARTHQUAKE HISTORY OF UTTAR PRADESH}

Most of the state of Uttar Pradesh lies in the Gangetic Plain and geologically this region is a fore-deep, a down warp of the Himalayan foreland, of variable depth, converted into flat plains by long-vigorous sedimentation. This Indo-Gangetic Geosyncline has shown considerable amounts of flexure and dislocation at the northern end and is bounded on the north by the Himalayan Frontal Thrust. The floor of the Gangetic trough (if see without all the sediments) is not an even plain, but shows corrugated inequalities and buried ridges (shelf faults). Beneath Uttar Pradesh, run the Delhi-Haridwar Ridge (DHR), trending NNE-SSW along New Delhi to the Garhwal region. The Delhi-Muzaffarnagar Ridge (DMR), which trends east to west, running from New Delhi to Kathgodam, in Nepal. The last ridge is the Faizabad ridge (FR), which runs in a curved manner, first east to west from Allahabad to Kanpur and then starts to bend towards the north-east towards Lucknow and carries on in this direction towards the Himalayas in Nepal. The depression that forms between the Delhi-Muzaffarnagar Ridge (DMR) and the Faizabad ridge 


\section{International Journal of Engineering Applied Sciences and Technology, 2020 Vol. 4, Issue 12, ISSN No. 2455-2143, Pages 362-372 \\ Published Online April 2020 in IJEAST (http://www.ijeast.com)}

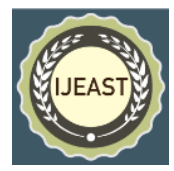

(FR), forms the West Uttar Pradesh shelf in the west and the Sharda Depression in the east. The region to the south of the Faizabad ridge forms the East Uttar Pradesh shelf. There are several faults in the region, among them the Moradabad Fault which trends NE-SW and the Bhairwan Fault in the vicinity of Allahabad. Apart from these there are east-west running tear faults in the region that control the courses of the main rivers. Earthquakes have occurred in mostly all parts of Uttar Pradesh. Major earthquakes in the neighbouring states of New Delhi, Uttarakhand, Bihar and from across the Indo-Nepal border have also shaken many parts of Uttar Pradesh. However, the proximity to faults does not necessarily translate into a higher hazard as compared to areas located further away, as damage from earthquakes depends on numerous factors such as subsurface geology as well as adherence to the building codes Since the earthquake database in India is still incomplete, especially with regards to earthquakes prior to the historical period (before 1800 A.D.), these zones offer a rough guide of the earthquake hazard in any particular region and need to be regularly updated.

Largest Instrumented Earthquake in Uttar Pradesh 10 October 1956 - Bulandshahr District (Uttar Pradesh), 6.2 (IMD) 15: 31:36 UTC, 28.20N, 77.70E One of the most powerful earthquakes in Uttar Pradesh struck the districts of western Uttar Pradesh at 21:01 IST on October 10th, 1956. The massive shock was centered in Bulandshahr District. No fatalities were reported. The shock was also strongly felt at Delhi, where there was some minor damage.

\subsection{Earthquake Catalogue}

The All India catalogue developed in the present study is a combination of instrumental, historic and pre-historic data. As such completeness of magnitudes in time has to be established before proceeding further. Here the widely used procedure proposed by Step (1972) is applied to determine the interval in a magnitude class over which the class is complete. The earthquake data is grouped into seven magnitude classes namely, $4 \leq \mathrm{Mw}$.

$\chi=\frac{1}{n} \sum_{i=1}^{n} x i$

Where $\mathrm{n}$ is the number of unit time intervals. The variance is given by

$\sigma_{x}^{2}=\frac{x}{T}$

Where $\mathrm{T}$ is the duration of the sample. If $\chi$ were to be constant, $\sigma \chi$ would vary as $1 / \sqrt{ } \mathrm{T}$. Following Step (1972) the standard deviation of the mean rate as a function of sample length are plotted along with nearly tangent lines with slope $1 / \sqrt{ }$ T. The deviation of standard deviation of the estimate of the mean from the tangent line indicates the length up to which a particular magnitude range may be taken to be complete. The standard deviation shows stability in shorter windows for smaller earthquakes and in longer time windows for large magnitude earthquakes. The standard deviation of the mean of the annual number of events as a function of sample length for the All India data is shown in Figure 3.3. This provides easy criteria for testing the completeness of the data. The results show that the All India data is complete for the sets $4 \leq \mathrm{Mw} 8$ for the past 50 (1958-2008), 110 (1898-2008), 130 (1878-2008), 340 (1668-2008) and 600 (1408-2008) years respectively. These intervals are marked also on Figure 1.2.

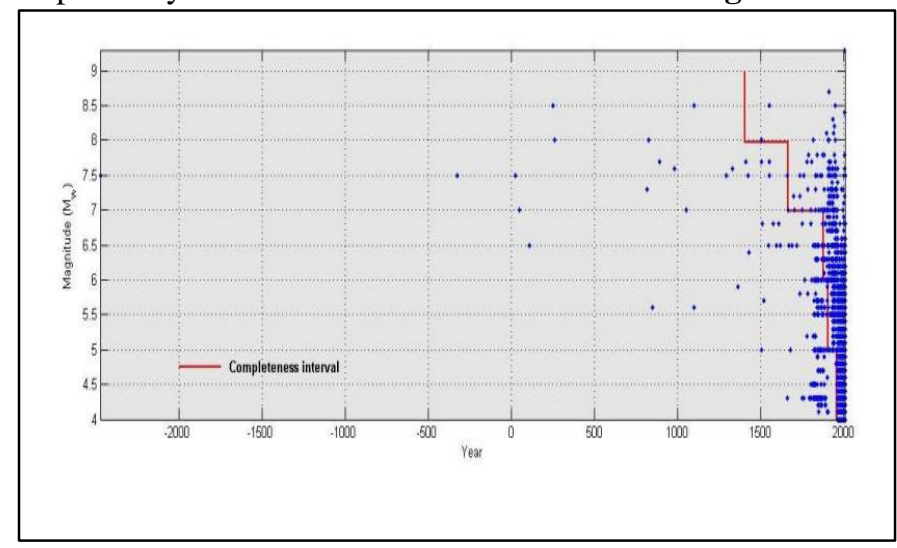

Figure- 1.2 Time distribution of earthquakes

All India Catalogue A catalogue containing all known events of magnitude $\mathrm{Mw} \geq 4$ for the region (20 - $400 \mathrm{~N}$; $610-1000 \mathrm{E})$ has been assembled for further work. The catalogue starts with the 2474 BC Dholavira earthquake in Gujarat with an approximated Mw of 7.5. A total of 38,860 events of magnitude $\mathrm{Mw} \geq 4$ known up to 31 st December 2008 are listed in the catalogue.

A common problem faced in assembling a catalogue is due to the different magnitude values reported in the literature. Here this is handled by converting all reported values to moment magnitude numbers. For the pre-instrumental period of the catalogue only MMI estimates were available. These have been converted to magnitude numbers using the empirical relation $\mathrm{Mw}=(2 / 3 \mathrm{MMI}+1)$. For many events IMD has reported only the local magnitude ML. This has been converted to Mw following the approach of Idriss (1985). For events from ISC, USGS catalogues with surface wave magnitude MS and body wave 20 magnitude mb the following conversion formulae of Scordilis (2006) derived on the basis of global data are used.

MS - MW

$\mathrm{Mw}=0.67 \mathrm{MS}+2.07$, for $(3.0 \leq \mathrm{MS} \leq 6.1) \mathrm{Mw}=0.99 \mathrm{MS}+$ 0.08 , for $(6.2 \leq \mathrm{MS} \leq 8.2)(3.1)$

$\mathrm{mb}-\mathrm{Mw}$

$\mathrm{Mw}=0.85 \mathrm{mb}+1.03$, for $(3.5 \leq \mathrm{mb} \leq 6.2)(3.2)$ The body wave magnitude saturates at the value of 6.2 .

\subsection{Completeness of the catalogue}

The All India catalogue developed in the present study is a combination of instrumental, historic and pre-historic data. As such completeness of magnitudes in time has to be established before proceeding further. Here the widely used procedure proposed by Stepp (1972) is applied to determine the interval in a magnitude class over which the class is complete. The earthquake data is grouped into seven magnitude classes namely, $4 \leq \mathrm{Mw} 8$ for the past 50 (1958-2008), 110 (18982008), 130 (1878-2008), 340 (1668-2008) and 600 (1408- 


\section{International Journal of Engineering Applied Sciences and Technology, 2020 \\ Vol. 4, Issue 12, ISSN No. 2455-2143, Pages 362-372 \\ Published Online April 2020 in IJEAST (http://www.ijeast.com)}

2008) years respectively. These intervals are marked also on Figure 3.2. The completeness for larger magnitudes is not verifiable for all the source zones since the average return period of great earthquakes would be longer than the time period spanned by the catalogue. Hence the catalogue is assumed to be complete for large magnitude earthquakes over the entire duration.

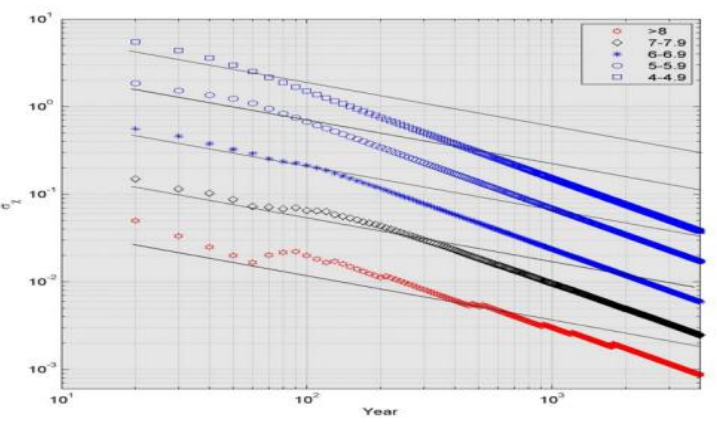

Figure 1.3 Completeness tests of All India earthquake data. Variation of $\sigma \chi$ versus time

\subsection{Vulnerability of Uttar Pradesh to Seismic Hazard}

Uttar Pradesh is India's most populous state, quite and a large part of this state lies in Earthquake High Damage Risk Zones IV and III.

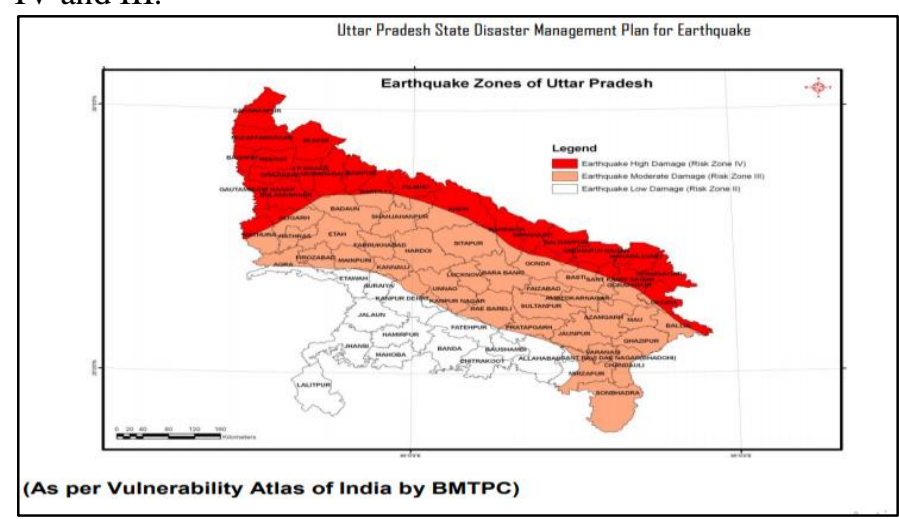

Figure 1.3 Earthquake Zones of Utttar Pradesh (As per Vulnerability Atlas of India by BMTPC)

Table 1.3: List of districts of Uttar Pradesh falling in Earthquake Damage Risk Zones (on the basis of Vulnerability Atlas of India by BMTPC)

\begin{tabular}{|c|c|c|c|c|}
\hline $\begin{array}{c}\text { Districts } \\
\text { completely } \\
\text { falling in } \\
\text { Earthquake } \\
\begin{array}{c}\text { Damage Risk } \\
\text { Zone IV }\end{array}\end{array}$ & $\begin{array}{c}\text { Districts } \\
\text { partly falling } \\
\text { in } \\
\text { Earthquake } \\
\text { Damage Risk } \\
\text { Zones IV \& } \\
\text { III }\end{array}$ & $\begin{array}{c}\text { Districts } \\
\text { completely } \\
\text { falling in } \\
\text { Earthquake } \\
\text { Damage Risk } \\
\text { Zone III }\end{array}$ & $\begin{array}{c}\text { Districts } \\
\text { partly falling } \\
\text { in } \\
\text { Earthquake } \\
\text { Damage } \\
\text { Risk Zone } \\
\text { III \& II }\end{array}$ & $\begin{array}{c}\text { Districts } \\
\text { completely } \\
\text { falling in } \\
\text { Earthquake } \\
\text { Damage } \\
\text { Risk Zone II }\end{array}$ \\
\hline District Name & $\begin{array}{c}\text { District } \\
\text { Name }\end{array}$ & District Name & $\begin{array}{c}\text { District } \\
\text { Name }\end{array}$ & $\begin{array}{c}\text { District } \\
\text { Name }\end{array}$ \\
\hline Baghpat & Aligarh & Ambedkar Nagar & Agra & Banda \\
\hline Bijnor & Bahraich & Azamgarh & Prayagraj & Chitrakoot \\
\hline G.B. Nagar & Ballia & Barabanki & Auriya & Hamirpur \\
\hline Ghaziabad & Balrampur & Chandauli & Etawah & Jalaun \\
\hline J.P. Nagar & Bareilly & Etah & Firozabad & Jhansi \\
\hline Kushinagar & Basti & Faizabad & Fatehpur & Kaushambi \\
\hline
\end{tabular}

\begin{tabular}{|c|c|c|c|c|}
\hline Maharajganj & Budaun & Farrukhabad & $\begin{array}{l}\text { Kanpur } \\
\text { (Dehat) }\end{array}$ & Lalitpur \\
\hline Meerut & Bulandsha & Kashiram Nagar & $\begin{array}{l}\text { Kanpur } \\
\text { (Nagar) }\end{array}$ & Mahoba \\
\hline Muzaffarr & Deoria & Hardoi & Mainpuri & \\
\hline Rampur & Gonda & Lucknow & Mirzapur & \\
\hline Saharanpur & Gorakhpur & Ghazipur & Pratapgarh & \\
\hline \multirow[t]{3}{*}{$\begin{array}{l}\text { Siddharth } \\
\text { Nagar }\end{array}$} & Pilibhit & Jaunpur & Raebareli & \\
\hline & $\begin{array}{c}\text { Lakhimpur } \\
\text { Khiri }\end{array}$ & Kannauj & $\begin{array}{c}\text { St. Ravi Das } \\
\text { Ngr }\end{array}$ & \\
\hline & Mathura & $\begin{array}{c}\text { Mahamaya } \\
\text { Nagar }\end{array}$ & Unnao & \\
\hline
\end{tabular}

1.8. Seismological Observatories, Seismic Zonation Studies: National status

The various maps show that there are some regions that are more active than others. This activity is correlated with the number of occurrence of past earthquakes and also with the presence of faults and lineaments. There is a possibility that not all past epicentres can be uniquely identified with particular faults.

The distribution of faults varies spatially as seen from Fig.1.5. Some specific patterns can be recognized about the faults and epicentres being dense in some regions. This pattern and the known tectonic disposition of India help us to demarcate thirty-two seismic source zones for further work.

In the past Khattri et al (1984) identified twenty-four source zones in India and neighbouring region on the basis of seismotectonics and historical seismicity. They recognized six zones in the Indian shield region, four in the Indo-Gangetic plain and the remaining fourteen zones distributed in the Himalayas, NEI and ANI. The region around the Killari earthquake of 1993 (Mw 6.3) was not recognized in this study. Bhatia et al (1999) identified eighty-five source zones based on past data. The Killari source zone was included in this study. The identified areal sources were smaller in size compared to that of Khattri et al (1984). Based on seismicity, tectonics and geodynamics, Parvez et al (2003) delineated forty seismogenic zones. Recently, Gupta (2006) identified eighty-one sources encompassing India and adjoining regions. In these studies, boundaries of the zones have been demarcated based on the presence of historical seismicity clusters. The source zones are spatially dense and contiguous in the Himalayas, Indo-Burmese range and the Andamans, whereas in the stable continental part of India large gaps are assumed. However in the Indo-Gangetic plain and the Indian shield, due to their weak activity historic information is scarce and hence the past seismic source zones are not robust. Hence based on historic data and geology, these authors divided the Indian shield into seven seismogenic zones without gaps.

Characterization of the seismicity of the identified thirty-two source zones in terms of the Gutenberg-Richter recurrence relation is possible after assembling an All India earthquake catalogue. 


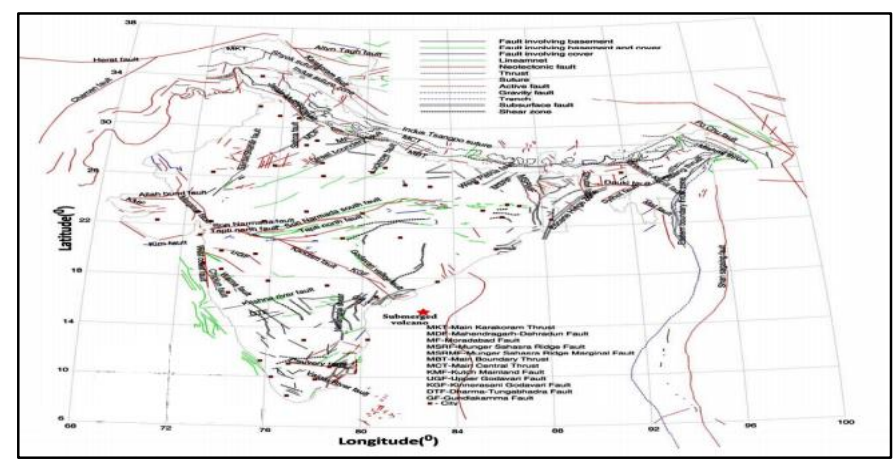

Figure 1.4 Fault Map of India. (Seismo-tectonic Atlas of GSI 2000; Valdiya 1976;

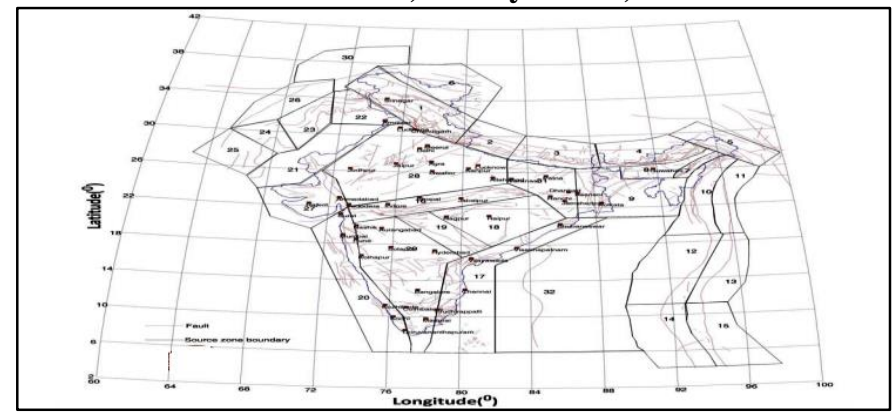

Figure 1.65 Thirty-two Seismogenic Zones of India

\section{METHODOLOGY}

The seismic hazard assessment at a site is mainly the function of source, path and site, and therefore, the primary need to identify the causative seismic sources. The source zones may presumably be considered as known faults, those have triggered seismicity in the past. The quantification of seismic potential of the source is normally carried out by assembling an earthquake catalogue containing past events of magnitude Mw 4.0 for the respective seismogenic source. We prepared a comprehensive earthquake catalogue, which has been statistically analyzed to characterize the identified zones in the backdrop of Gutenberg-Richter (GUTENBERG and RICHTER, 1944) recurrence relation and maximum expected earthquake magnitude (Mmax).

\subsection{Seismic Hazard Analysis}

Seismic hazard analysis involves the quantitative estimation of ground shaking hazards at a particular area. Seismic hazards can be analyzed deterministically as and when a particular earthquake scenario is assumed, or probabilistically, in which uncertainties in earthquake size, location, and time of occurrence are explicitly considered (Kramer, 1996). A critical part of seismic hazard analysis is the determination of Peak Ground Acceleration (PGA) and response acceleration (spectral acceleration) for an area/site. Spectral acceleration (Sa) is preferred for the design of civil engineering structures. It is an accepted trend in engineering practice to develop design response spectrum for different types of foundation materials such as rock, hard soil and weak soils. Analysis of lineaments and faults helps in understanding the regional seismotectonic activity of the area. Lineaments are linear features seen on the surface of earth which represents faults, features, shear zones, joints, litho contacts, dykes, etc; and are of great relevance to geoscientists.

\section{A. Deterministic Seismic Hazard Analysis (DSHA)}

Krinitzsky (2005) highlights that a Deterministic Seismic Hazard Analysis (DSHA) uses geology and seismic history to identify earthquake sources and to interpret the strongest earthquake each source is capable of producing regardless of time, because that earthquake might happen tomorrow. Those are the Maximum Credible Earthquakes (MCEs), the largest earthquakes that can reasonably be expected. As we cannot safely predict when an earthquake will happen, the MCEs are what a critical structure should be designed for if the structure is to avoid surprises. Deterministic seismic hazard assessment is carried out to identify the Maximum Credible Earthquake (MCE) that will affect a site. The MCE is the largest earthquake that appears possible along a recognized fault under the presently known or presumed tectonic activity (USCOLD, 1995), which will cause the most severe consequences to the site.

Using these details and regional attenuation relation developed for southern India by Iyengar and Raghukanth (2004), the peak ground acceleration (PGA) has been estimated. To estimate the expected magnitude for seismic source, a parametric study has been carried out to find subsurface rupture length of the fault using past earthquake data and Wells and Coppersmith (1994) relation between the subsurface lengths versus earthquake magnitudes. About more than $60 \%$ of earthquake magnitude matches with the subsurface length corresponding to $3.8 \%$ of the total length of fault. The expected maximum magnitude for each source has been evaluated by assuming that the seismic source can be ruptured at subsurface level for a length of $3.8 \%$ of the total length of source. The PGA for uttar pradesh has been estimated using expected magnitudes and regional attenuation relation. Further seismological model developed by Boore (1983, 2003), SMSIM program, has been used to generate synthetic ground motions for sources resulting higher PGA in the above two methods 1 ) using regional attenuation equation and largest earthquake close to source, and, 2) using regional attenuation equation and expected maximum magnitude arrived by assuming subsurface rupture length. The seismic sources ( 8 numbers) causing considerable PGA value from the method I, and II, are further used for generating the synthetic ground motions.

\section{Synthetic Earthquake Model and Peak ground acceleration map}

For microzonation, the study of local site effects need to be carried out for a scenario earthquake estimated in the seismic 
hazard analysis. To study the local site effects of earthquake in the local scale level, the scenario earthquake record/ground motion in the form of time series is required. For the area having limited seismic record, synthetic ground motion models is the alternative (as the study area lacks ground motion records). Modeling of strong motion helps to estimate future hazard of the region and study the local soil effects in local scale. For south India, Iyengar and Raghukanth (2004) have developed ground motion attenuation relation based on the statistically simulated seismological model. Seismological model by Boore (1983) is used for generation of synthetic acceleration-time response (Atkinson and Boore 1995, Hwang and Huo 1997). The synthetic ground motion and spectral acceleration at rock level for 8 seismic sources are developed by considering expected magnitude and hypocentral distance along with the above regional seismic hazard parameters. The PGA values obtained from synthetic ground motion model using regional seismotectonic parameters varies from $0.005 \mathrm{~g}$ to $0.136 \mathrm{~g}$. The lineament L15 gives the highest PGA value of $0.136 \mathrm{~g}$ by taking hypocentral distance of $15.88 \mathrm{~km}$. Further, PGA obtained from the model for the L15 matches well with the PGA values from both the above approaches.

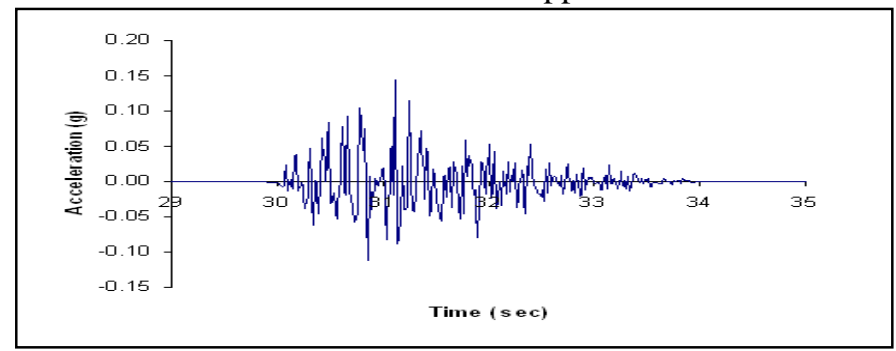

\section{B. Probabilistic Seismic Hazard Analysis (PSHA)}

PSHA is the most commonly used approach to evaluate the seismic design load for the important engineering projects. PSHA method was initially developed by Cornell (1968) and its computer form was developed by McGuire (1976 and 1978) and Algermissen and Perkins (1976). McGuire developed EqRisk in the year 1976 and FRISK in the year 1978. Algermissen and Perkins (1976) developed RISK4a, presently called as SeisRisk III. Site ground motions are estimated for selected values of the probability of ground motion exceedance in a design period of the structures or for selected values of annual frequency or return period for ground motion exceedance. The probabilistic approach offers a rational framework for risk management by taking account of the frequency or probability of exceedance of the ground motion against which a structure or facility is designed. The occurrence of earthquakes in a seismic source is assumed as the Poisson distribution. The probability distribution is defined in terms of the annual rate of exceeding the ground motion level $\mathrm{z}$ at the site under consideration, due to all possible pairs (M, R) of the magnitude and epicentral distance of the earthquake event expected around the site, considering its random nature.

\section{Rupture based seismic hazard analysis (RBSHA)}

Most of the hazard analyses/zonations are being carried out considering the past earthquake location, size, and rate of occurrence of past earthquakes on the fault or in the region for future design of structures. Moderate to major earthquakes need sufficient energy to rupture the faults. Time required to buildup the required energy to create moderate to major earthquakes is a region-specific. So, interval between two consecutive earthquakes in the same location is considerable, but it is accounted poorly in the hazard analysis and future seismic zonation. Earthquakes relive the strain energy that builds up on faults; next earthquake in the region is more likely to occur in areas where little or no seismic activity has been observed for some time (Kramer 1996). Based on the average return period of earthquakes in the region, one can assess the potential of past earthquake location for generating the future similar earthquakes. Let the place/source having earthquake magnitude of $\mathrm{M}$ with an average return period of $\mathrm{T}$ has ruptured by an amount of $\mathrm{R}$. Amount of rupture depends on the seismotectonic of the region and seismic sources. Maximum magnitude reported in the region is Mmax and $\mathrm{M}$ is the average damaging earthquake in the region. If $\mathrm{M}$ and $\mathrm{Mmax}$ are relatively comparable, the possibility of occurrence of the same M or Mmax in the same (reported past) location is rare up to period $\mathrm{T}$. Hence, for the future seismic zonation for period less than $\mathrm{T}$, these locations can be eliminated or considered as areas with no potential for occurrence of nearfuture earthquake. But in the conventional hazard analysis for future zonation of time period less than $\mathrm{T}$, these locations are considered and probable magnitude is arrived by adding 0.3 to 1 more to Mmax. Also, possibility of occurrence of damaging earthquake in other locations/sources is not accounted. In order to account the possibility of occurrence of earthquake in the locations other than past damaging earthquake locations, a new seismic hazard analysis has been attempted in this paper that is named as $\boldsymbol{R} \boldsymbol{B S H \boldsymbol { A }}$

\section{RESULT AND DISCUSSION}

\subsection{Fault Deggregation}

Let the number of earthquakes per year with $\mathrm{m}>\mathrm{m} 0$ in a given source zone consisting of $n$ number of faults be denoted as $\mathrm{N}(\mathrm{m} 0)$. Since all these events are associated with the faults within the zone, it follows $\mathrm{N}(\mathrm{m} 0)=\sum \mathrm{Ns}(\mathrm{m} 0)$ where $\mathrm{Ns}(\mathrm{m} 0)$ stands for the annual frequency of event $(\mathrm{m}>\mathrm{m} 0)$ on the s-th fault $(s=1,2,3, n)$. This conservation property can be heuristically used to develop G-R relations for each fault in the source zone. Here we take $(\mathrm{m} 0=4)$ for further work. The number of events Ns (m0) that can occur on a given fault depends on a variety of factors, the most important being the potential of the fault to break depending on its length and known past activity. This argument just reiterates that a long fault is capable of breaking into more number of smaller 


\section{International Journal of Engineering Applied Sciences and Technology, 2020 \\ Vol. 4, Issue 12, ISSN No. 2455-2143, Pages 362-372 \\ Published Online April 2020 in IJEAST (http://www.ijeast.com)}

sections. At the same time a shorter fault might be more active contributing to more small magnitude events in the catalogue. Thus two parameters namely the fault length Ls and the number of past events ns associated with the s-the fault have to be used as weights for finding $\mathrm{Ns}(\mathrm{m} 0)$. If $\mathrm{Nz}$ number of events is available in the zonal catalogue we get two weights for each fault within the zone as,

$$
\alpha \mathrm{s}=\mathrm{Ls} / \sum \mathrm{Ls} \text { and } \delta \mathrm{s}=\mathrm{ns} / \mathrm{Nz}
$$

Taking the mean of the above two factors as indicating the seismic activity of the s-th fault in the zone we get

$$
\mathrm{Ns}(\mathrm{m} 0)=0.5(\alpha \mathrm{s}+\delta \mathrm{s}) \mathrm{N}(\mathrm{m} 0)
$$

as the a-value in the G-R relation of the s-th fault. The b-value for all the faults is taken to be constant equal to the zonal bvalue. A further constraint appears in the form of the maximum possible magnitude mu that can be foreseen on a given fault, depending on its length. This has to be less than the zonal potential but can be higher than the past magnitudes associated with the particular fault. Here it is taken to be half unit more than the past maximum magnitude. In the absence of past activity mu is estimated depending on the length of the fault using the empirical relation proposed by Wells and Coppersmith (1994).

\subsection{Probabilistic Seismic Hazard Analysis (PSHA)}

With the help of the source and the path database we are now in a position to carry out PSHA for any grid point in Fig. 5.3. The procedure for carrying out PSHA is well known. The uncertainty in the magnitude of a future event is represented as an exponential random variable

$P_{m}(m)=\frac{\beta e^{-\beta(m-m o)}}{1-\beta e^{-\beta(m u-m o)}} ;(m o \leq m \leq m u), \beta=2.303 \mathrm{~b}$

The other unknown factor is the distance $\mathrm{R}$ of the site to the future hypocenter The conditional probability distribution function of $\mathrm{R}$, given that magnitude $\mathrm{M}=\mathrm{m}$ for a rupture segment uniformly distributed along a fault can be numerically computed following the method of Der Kiureghian and Ang (1977) .

$$
\begin{aligned}
& \mathrm{P}(\mathrm{R}<\mathrm{r} \mid \mathrm{M}=\mathrm{m})=0 \text { for } \mathrm{R}<\left(D^{2}+L^{2}\right)^{1 / 2} \\
& \mathrm{P}(\mathrm{R}<\mathrm{r} \mid \mathrm{M}=\mathrm{m})=\frac{\left(r^{2}-D^{2}\right)^{1 / 2}-L o}{L-X(m)} \\
& \left.\quad \text { for } D^{2}+L^{2}\right)^{1 / 2} \leq R<\left\{D^{2}+[L+L o-X(m)]^{2}\right\}^{1 / 2} \\
& \mathrm{P}(\mathrm{R}<\mathrm{r} \mid \mathrm{M}=\mathrm{m})=1 \text { for } \mathrm{R}>\left\{D^{2}+[L+L o-X(m)]^{2}\right\}^{1 / 2}
\end{aligned}
$$

The rupture length, $X(\mathrm{~m})$, for an event of magnitude $\mathrm{m}$, is given by

$$
X_{(m)}=\operatorname{MIN}\left[10^{(-2.44+0.59 m)}, \text { fault length }\right]
$$

Probabilistic seismic hazard analysis estimates the probability of exceedance of spectral acceleration $\mathrm{Sa}$ at a site due to all possible future earthquakes as visualized by the previous hazard scenario. Assuming that the number of earthquakes occurring on a fault follows a stationary Poisson process, the probability that the control variable $\mathrm{Y}$ exceeds level $\mathrm{y}^{*}$, in a time window of $\mathrm{T}$ years is given by

$\mathrm{P}\left(\mathrm{Y}>\mathrm{y}^{*}\right.$ in $\mathrm{T}$ years $)=1-\exp (-\mathrm{up} * \mathrm{~T})$

The rate of exceedance, $\mu y^{*}$ is computed from the expression $\mu_{y^{*=} \sum_{i=1}^{k} N i\left(m_{o}\right) \int m \int r P}\left(Y>y^{*} \mid m, r\right) p_{R \mid M}\left(R \mid M\left(\frac{r}{m}\right) p_{m}(m) d r d m\right.$ Here, $\mathrm{K}$ is the total number of faults in the zone, $\mathrm{pM}(\mathrm{m})$ and $\mathrm{pR} \mid \mathrm{M}(\mathrm{r} \mid \mathrm{m})$ are the probability density functions of magnitude and hypocentral distance respectively. $\mathrm{P}\left(\mathrm{Y}>\mathrm{y}^{*} \mid \mathrm{m}, \mathrm{r}\right)$ is the conditional probability of exceedance of the ground motion parameter $\mathrm{Y}$. This is found as a lognormal random variable with mean value given by the attenuation equation conditioned on particular $\mathrm{m}$ and $\mathrm{r}$ values.

\subsection{All India PSHA Maps}

Probabilistic seismic hazard analysis for PGA, and spectral accelerations corresponding to periods 0.5 and 1.25 seconds has been carried out for all the grid points spread over the Indian land mass. The final results valid for A-type sites are presented as contour maps for return periods $475(\sim 500)$, and 2475 ( 2500) years. These are shown in Figures given below. For developing design response spectrum as per the International Building Code IBC-2009, one needs spectral acceleration values at 0.2 -second and 1-second periods corresponding to 2500 year return period. These results are shown in Figures 3.1. The PGA values at 48 important cities in India are also reported in Table 5.4 for two return periods.

Table 3.1. Zone $27(\mathrm{~b},=0.87 ; \mathrm{N}(\mathrm{m} 0),=1.31$ and $\mathrm{Mmax}=8.0)$

\begin{tabular}{|l|l|l|l|l|l|l|}
\hline $\begin{array}{l}\text { Fault } \\
\text { numb } \\
\text { er }\end{array}$ & $\begin{array}{l}\text { Fault } \\
\text { length } \\
\text { (km) }\end{array}$ & $\begin{array}{c}\text { No. of } \\
\text { past } \\
\text { events }\end{array}$ & $\mathbf{m}_{\mathbf{u}}$ & $\boldsymbol{\alpha}_{\mathbf{s}}$ & $\boldsymbol{\delta}_{\mathbf{s}}$ & $\mathbf{N}_{\mathbf{s}}\left(\mathbf{m}_{\mathbf{o}}\right)$ \\
\hline 98 & 15.33 & 3 & 8.0 & 0.0055 & 0.0217 & 0.0178 \\
\hline 106 & 205.52 & 11 & 6.1 & 0.0736 & 0.0797 & 0.1004 \\
\hline 107 & 209.27 & 44 & 8.0 & 0.0750 & 0.3188 & 0.2579 \\
\hline 108 & 47.12 & 7 & 7 & 0.0169 & 0.0507 & 0.0443 \\
\hline 109 & 78.47 & 1 & 4.9 & 0.0281 & 0.0072 & 0.0232 \\
\hline 110 & 168.58 & 1 & 5.5 & 0.0604 & 0.0072 & 0.0443 \\
\hline 111 & 422.09 & 3 & 6.7 & 0.1512 & 0.0217 & 0.1133 \\
\hline 144 & 144.51 & 4 & 6.1 & 0.0518 & 0.0290 & 0.0529 \\
\hline 334 & 16.54 & 0 & 6.7 & 0.0059 & 0 & 0.0039 \\
\hline 414 & 29.64 & 0 & 7.1 & 0.0106 & 0 & 0.0070 \\
\hline 415 & 19.74 & 4 & 6.2 & 0.0071 & 0.0290 & 0.0236 \\
\hline 416 & 113.75 & 3 & 5.6 & 0.0407 & 0.0217 & 0.0409 \\
\hline 417 & 26.57 & 0 & 7.0 & 0.0095 & 0 & 0.0061 \\
\hline 418 & 37.95 & 2 & 4.6 & 0.0136 & 0.0145 & 0.0184 \\
\hline 420 & 25.82 & 0 & 6.98 & 0.0093 & 0 & 0.0061 \\
\hline 699 & 40.87 & 0 & 7.28 & 0.0146 & 0 & 0.0096 \\
\hline 700 & 293.26 & 5 & 4.7 & 0.1050 & 0.0362 & 0.0925 \\
\hline 753 & 60.09 & 5 & 6.2 & 0.0215 & 0.0362 & 0.0378 \\
\hline 754 & 184.19 & 1 & 4.9 & 0.0674 & 0.0072 & 0.0489 \\
\hline 759 & 311.71 & 13 & 6.5 & 0116 & 0.0942 & 0.1348 \\
\hline 780 & 41.49 & 3 & 5.5 & 0.0149 & 0.0217 & 0.0240 \\
\hline 781 & 184.03 & 1 & 4.7 & 0.0659 & 0.0072 & 0.0479 \\
\hline 782 & 111.33 & 27 & 6.3 & 0.0399 & 0.1957 & 0.1543 \\
\hline & & & & & & \\
\hline
\end{tabular}




\section{RESULTS}

\begin{tabular}{|c|c|c|c|c|c|c|}
\hline Agglomeration & $\begin{array}{l}\text { Latitu } \\
\text { de }\end{array}$ & $\begin{array}{l}\text { Longit } \\
\text { ude }\end{array}$ & $\begin{array}{l}\text { PGA } \\
500)\end{array}$ & $\begin{array}{l}\text { PGA } \\
2500)\end{array}$ & $\begin{array}{l}\text { PGA } \\
5000)\end{array}$ & $\begin{array}{l}\text { PGA1 } \\
0000)\end{array}$ \\
\hline Guwahati & 26.17 & 91.77 & 0.23 & 0.37 & 0.42 & 0.51 \\
\hline Chandigarh & 30.75 & 76.78 & 0.10 & 0.19 & 0.25 & 0.32 \\
\hline Kolkata & 22.55 & 88.37 & 0.09 & 0.19 & 0.24 & 0.31 \\
\hline Mumbai & 19.00 & 72.80 & 0.09 & 0.19 & 0.25 & 0.32 \\
\hline Jabalpur & 23.15 & 79.93 & 0.08 & 0.18 & 0.24 & 0.31 \\
\hline Asansol & 23.68 & 86.98 & 0.08 & 0.17 & 0.21 & 0.27 \\
\hline Delhi & 28.62 & 77.22 & 0.08 & 0.17 & 0.22 & 0.29 \\
\hline Srinagar & 34.08 & 74.78 & 0.08 & 0.16 & 0.21 & 0.26 \\
\hline Jaipur & 26.92 & 75.82 & 0.07 & 0.16 & 0.17 & 0.28 \\
\hline Meerut & 28.99 & 77.70 & 0.06 & 0.14 & 0.18 & 0.23 \\
\hline Agra & 27.18 & 78.02 & 0.06 & 0.14 & 0.18 & 0.25 \\
\hline Ahmedabad & 23.03 & 72.57 & 0.07 & 0.14 & 0.17 & 0.24 \\
\hline Vijayawada & 16.51 & 80.61 & 0.07 & 0.13 & 0.15 & 0.21 \\
\hline Jamshedpur & 22.80 & 86.18 & 0.07 & 0.12 & 0.14 & 0.20 \\
\hline Dhanbad & 23.80 & 86.45 & 0.06 & 0.11 & 0.13 & 0.18 \\
\hline Pune & 18.52 & 73.85 & 0.06 & 0.11 & 0.13 & 0.16 \\
\hline Kozhikode & 11.25 & 75.77 & 0.05 & 0.10 & 0.09 & 0.17 \\
\hline Kolhapur & 16.70 & 74.23 & 0.05 & 0.10 & 0.11 & 0.11 \\
\hline Rajkot & 22.30 & 70.78 & 0.05 & 0.09 & 0.11 & 0.13 \\
\hline Vadodara & 22.30 & 73.20 & 0.05 & 0.09 & 0.10 & 0.16 \\
\hline T'nant & 8.480 & 76.95 & 0.04 & 0.08 & 0.10 & 0.11 \\
\hline hapura & 9.970 & 76.27 & 0.03 & 0.08 & 0.11 & 0.13 \\
\hline Kochi & 30.91 & 75.85 & 0.04 & 0.08 & 0.10 & 0.14 \\
\hline Ludhiana & 22.42 & 75.54 & 0.04 & 0.08 & 0.10 & 0.12 \\
\hline Indore & 25.60 & 85.12 & 0.04 & 0.08 & 0.11 & 0.13 \\
\hline Patna & 26.83 & 80.92 & 0.04 & 0.08 & 0.11 & 0.17 \\
\hline Lucknow & 26.46 & 80.33 & 0.03 & 0.08 & 0.11 & 0.17 \\
\hline Kanpur & 21.23 & 72.78 & 0.04 & 0.08 & 0.09 & 0.14 \\
\hline Surat & 10.81 & 78.69 & 0.04 & 0.07 & 0.09 & 0.11 \\
\hline Trichy & 23.35 & 85.33 & 0.03 & 0.07 & 0.09 & 0.11 \\
\hline Ranchi & 25.45 & 81.85 & 0.03 & 0.07 & 0.09 & 0.13 \\
\hline Allahabad & 31.64 & 74.86 & 0.03 & 0.07 & 0.09 & 0.11 \\
\hline Amritsar & 11.04 & 76.96 & 0.04 & 0.07 & 0.09 & 0.11 \\
\hline Coimbatore & 21.15 & 79.08 & 0.04 & 0.07 & 0.09 & 0.10 \\
\hline Nagpur & 26.28 & 73.02 & 0.03 & 0.06 & 0.08 & 0.11 \\
\hline Jodhpur & 20.00 & 73.78 & 0.03 & 0.06 & 0.08 & 0.10 \\
\hline Nashir & 26.14 & 78.10 & 0.02 & 0.05 & 0.07 & 0.10 \\
\hline Gwalior & 9.800 & 78.10 & 0.03 & 0.05 & 0.07 & 0.10 \\
\hline Madurai & 25.32 & 82.98 & 0.02 & 0.05 & 0.06 & 0.07 \\
\hline Varanasi & 23.25 & 77.42 & 0.03 & 0.05 & 0.07 & 0.09 \\
\hline Bhopal & 17.37 & 78.48 & 0.02 & 0.05 & 0.06 & 0.07 \\
\hline Hyderabad & 13.05 & 80.27 & 0.03 & 0.05 & 0.06 & 0.07 \\
\hline Chennai & 17.68 & 75.92 & 0.02 & 0.04 & 0.05 & 0.06 \\
\hline Solapur & 20.27 & 85.84 & 0.02 & 0.04 & 0.05 & 0.06 \\
\hline Bhubaneswar & 12.97 & 77.58 & 0.02 & 0.04 & 0.05 & 0.06 \\
\hline Bangalore & 19.78 & 75.29 & 0.02 & 0.03 & 0.03 & 0.04 \\
\hline Aurangabad & 17.07 & 83.25 & 0.02 & 0.03 & 0.04 & 0.04 \\
\hline Visakhapatnam & 21.23 & 81.63 & 0.01 & 0.02 & 0.02 & 0.03 \\
\hline
\end{tabular}

Table 4.1. Relative Seismic Hazard Other Cities in PGA

Table 4.2. Relative Seismic Hazard of Cities in Uttar Pradesh on A-type Sites in terms of PGA

\begin{tabular}{|l|l|l|l|l|l|l|}
\hline $\begin{array}{l}\text { Agglome } \\
\text { ration }\end{array}$ & Lat. & Long. & $\begin{array}{l}\text { PG } \\
\mathbf{A} \\
\text { TR= } \\
\mathbf{5 0 0}\end{array}$ & $\begin{array}{l}\text { PGA } \\
\text { TR=250 } \\
\mathbf{0}\end{array}$ & $\begin{array}{l}\text { PGA } \\
\text { TR=5000 }\end{array}$ & $\begin{array}{l}\text { PGA } \\
\text { TR=10000 }\end{array}$ \\
\hline Lucknow & 26.83 & 80.92 & 0.04 & 0.08 & 0.11 & 0.17 \\
\hline Kanpur & 26.46 & 80.333 & 0.03 & 0.08 & 0.11 & 0.17 \\
\hline Meerut & 28.99 & 77.70 & 0.06 & 0.14 & 0.18 & 0.23 \\
\hline Agra & 27.18 & 78.02 & 0.06 & 0.14 & 0.18 & 0.25 \\
\hline Praygraj & 25.45 & 81.85 & 0.03 & 0.07 & 0.09 & 0.13 \\
\hline Varansi & 25.32 & 82.98 & 0.02 & 0.05 & 0.06 & 0.07 \\
\hline
\end{tabular}

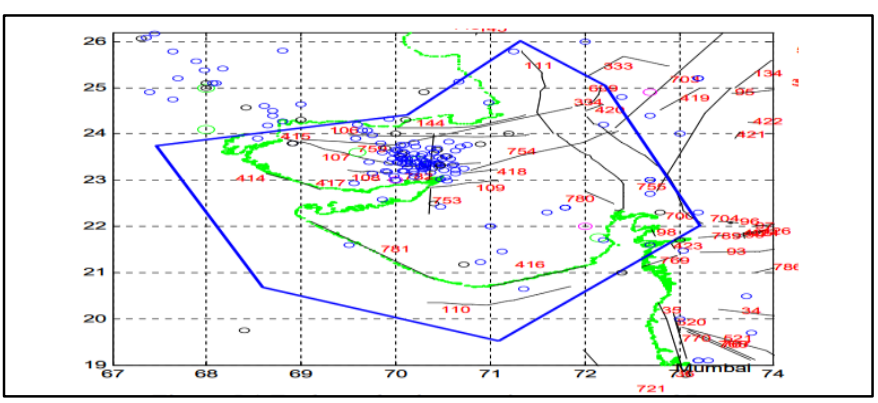

Figure 4.1. Faults and epicenters in source zone 27

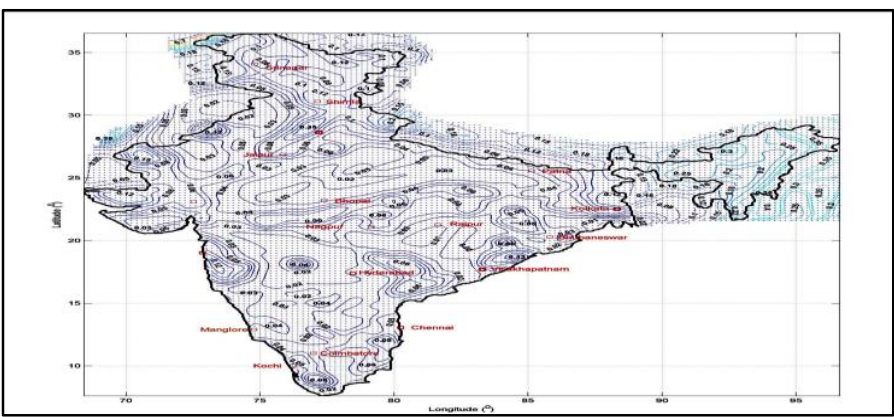

Figure 4.2 PGA Contours with $10 \%$ probability of exceedence in 50 years (Return Period $\sim 500$ years) on Atype Sites

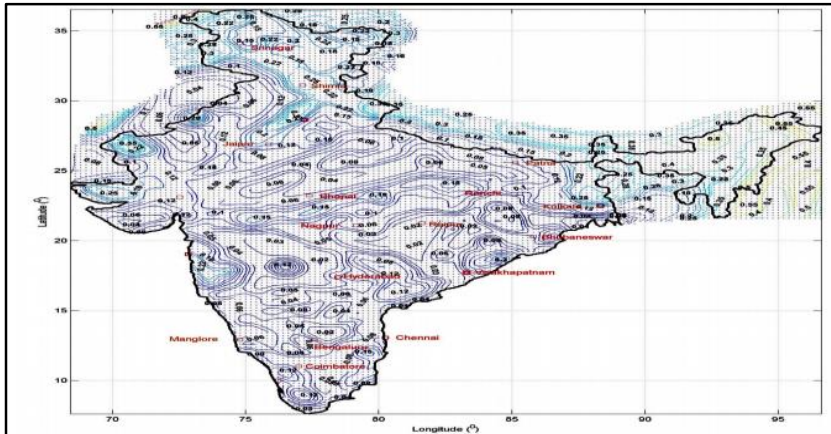

Figure 4.3. PGA Contours with $2 \%$ probability of exceedence in 50 years (Return Period)

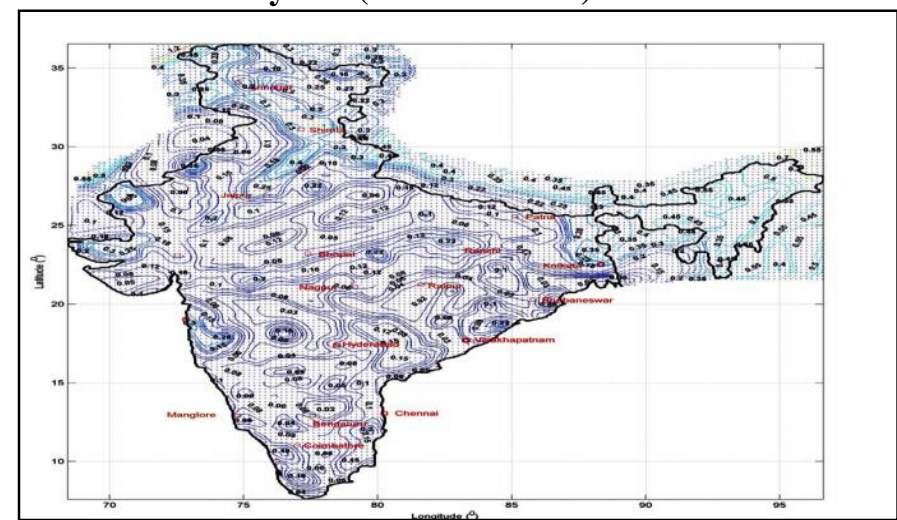

Figure 4.4. PGA Contours with Return Period of $\sim 5000$ years on A-type Sites 


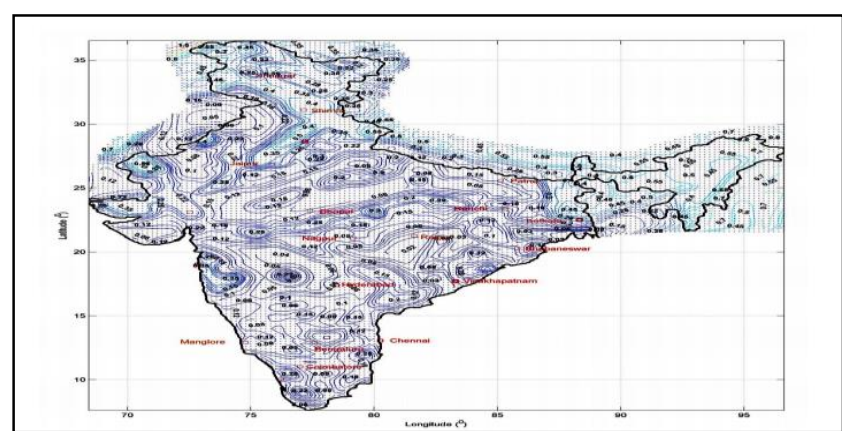

Figure 4.5 PGA Contours with Return Period of $\sim 10,000$ years on A-type Sites

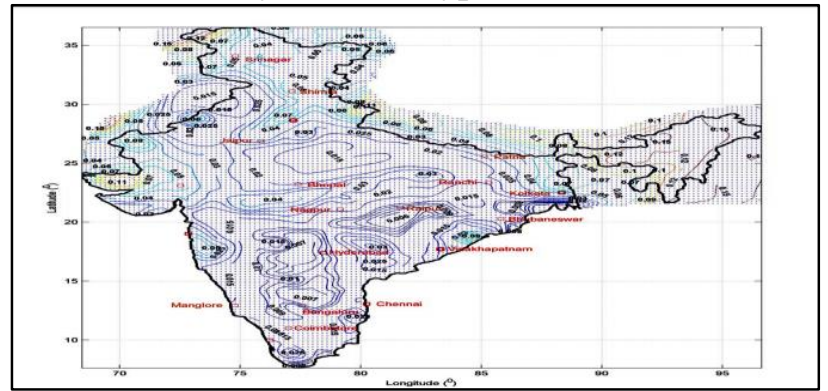

Figure 4.6. Spectral Acceleration at $\mathrm{T}=0.5 \mathrm{sec}$ and $5 \%$ damping with $10 \%$ probability of Exceedence in 50 years (Return Period $\sim 500$ years) on A-type sites

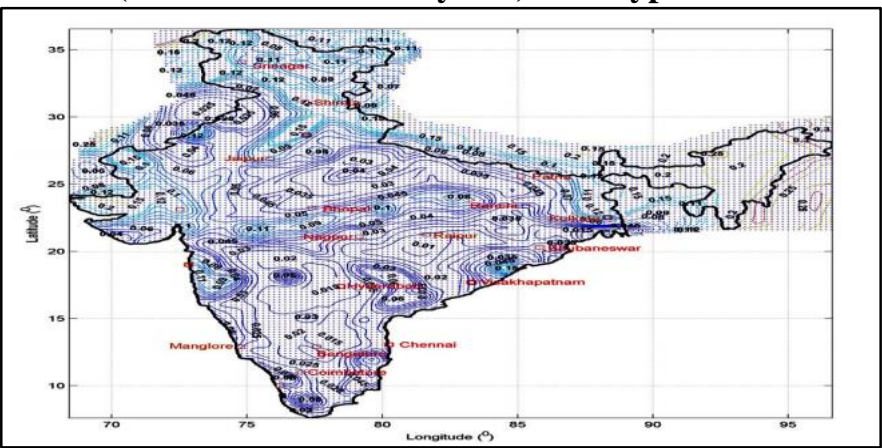

Figure 4.7. Spectral Acceleration at $\mathrm{T}=\mathbf{0 . 5 \mathrm { sec }}$ and $5 \%$ damping with $2 \%$ probability of exceedence in 50 years (Return Period 2500 years) on A-type sites

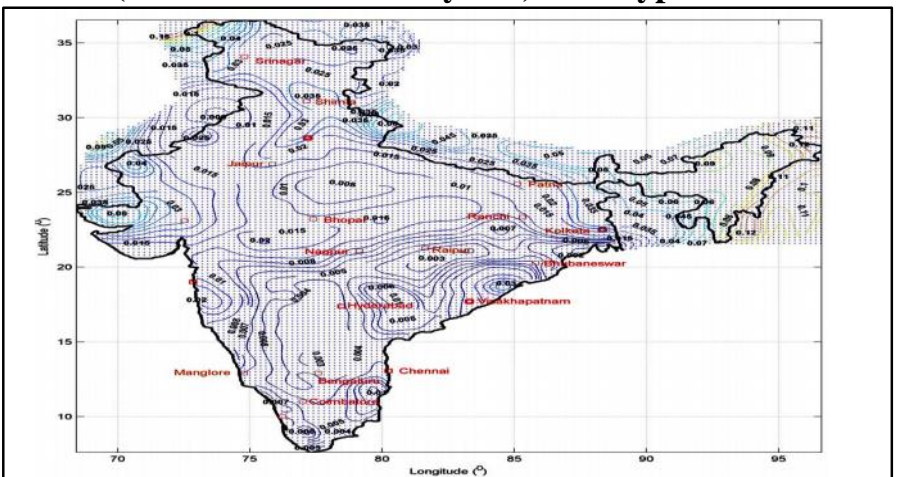

Figure 4.8 Spectral Acceleration at $\mathrm{T}=\mathbf{1 . 2 5} \mathrm{sec}$ and 5\% damping with $10 \%$ probability of exceedence in 50 years (Return Period $\sim 500$ years) on A-type Sites

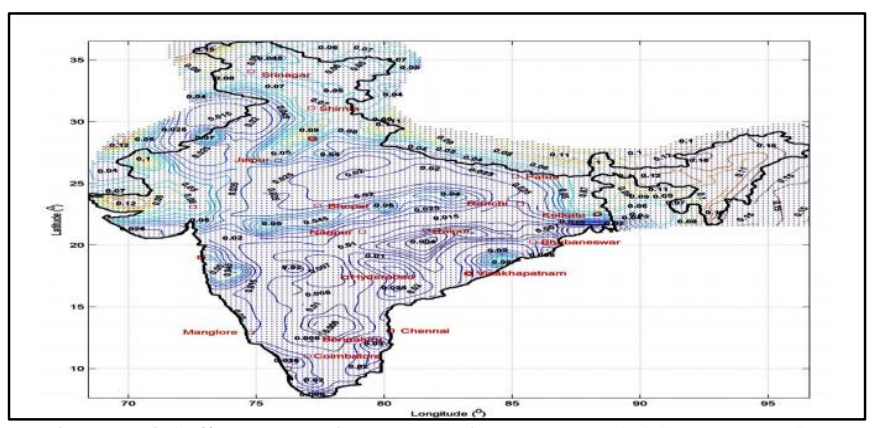

Figure 4.9 Spectral Acceleration at $\mathrm{T}=1.25 \mathrm{sec}$ and $5 \%$ damping with $2 \%$ probability of exceedence in $\mathbf{5 0}$ years (Return Period 2500 years) on A-type Sites

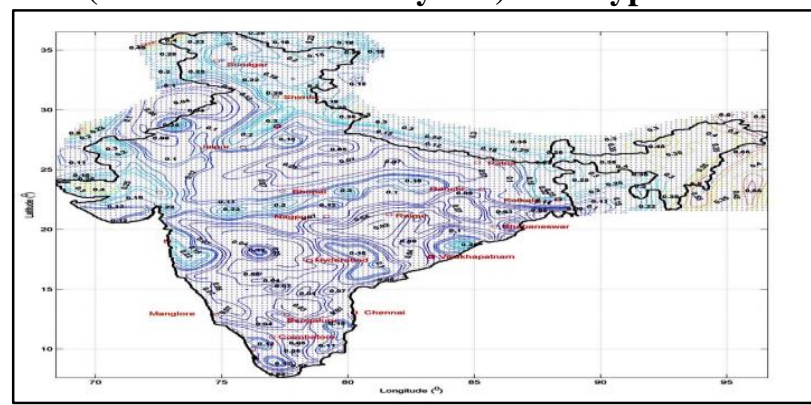

Figure 4.10. Short Period Spectral Acceleration at $\mathrm{T}=0.2$ second with Return Period of 2500 years on A-type Sites (5\% damping)

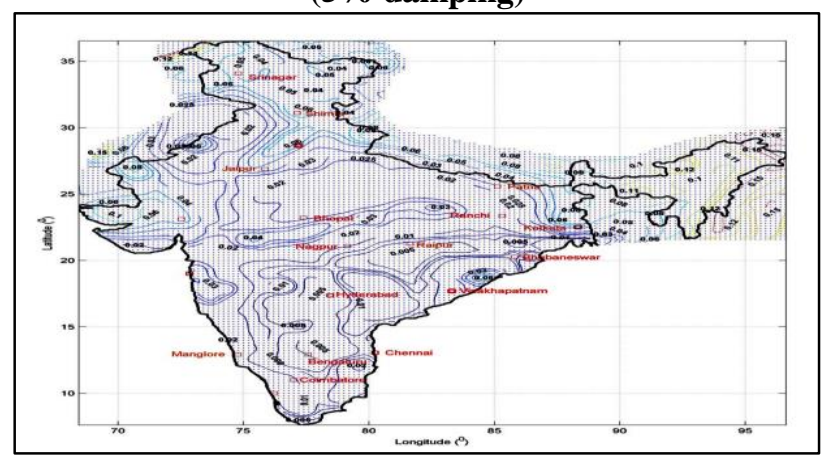

Figure 4.11. Long Period Spectral Acceleration at $T=1$ second with Return Period of 2500 years on A-type Sites (5\% damping)

\section{CONCLUSION}

The present article investigates the seismic hazard for U.P using the probability theory with a new data set. The seventeen numbers of pertinent faults and lineaments are identified from the seismotectonic map of the area, which have a significant influence on ground motion. Since the slip rate for individual faults is not available, the regional recurrence relation for the region was developed using the historic and instrumental database in this study. The designed spectra developed in this study incorporate uncertainties in location, magnitude and recurrence earthquakes, and, hence, are superior to spectra recommended by IS 1893-2002. The result presented here can be directly used to reconstruct a 


\section{International Journal of Engineering Applied Sciences and Technology, 2020 Vol. 4, Issue 12, ISSN No. 2455-2143, Pages 362-372 \\ Published Online April 2020 in IJEAST (http://www.ijeast.com)}

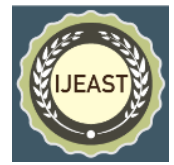

Microzonation map for U.P through detailed geotechnical investigations. A seismic hazard map covering U.P and its environs on a finer grid will cater to the needs of precise disaster management.

\section{ACKNOWLEDGEMENT}

Acknowledgments The authors would like to thank the Ministry of Earth Science (MoES) 'Site Characterization of Uttar Pradesh with studies of Site Response \& Liquefaction Hazard' , Indian Meteorological Department (IMD), GSI(Geological Survey of India.) (2000) Seismotectonic Atlas of India \& Uttar Pradesh State Disaster Administration.

\section{REFERENCES}

[1] Gupta Kishor Shravan, Kumar Arvind , Tomar Amit Kumar, (July 2016)

[2] "Seismic Hazard Assessment of Uttar Pradesh" SSRG International Journal of Civil Engineering ( SSRG - IJCE ) - Volume 3 Issue 7

[3] Agarwal, P., and Shrikhande, M., (2006)," Earthquake resistant design of structures”, PHI Learning Pvt. Ltd., New Delhi

[4] Gutenberg, B. and C. F. Richter (1944). Frequency of earthquakes in California, Bull. Seism. Soc. Am. 34, 185188

[5] GSI (2000) Seismotectonic Atlas of India and Its Environs. Geological Survey of India.

[6] IS: 1893 (Part 1)-2016, Bureau of Indian Standard (BIS) (2016) revised its code of practice, Criteria for Earthquake Resistant Design of Structures.

[7] IMD http://www.imd.gov.in/

[8] Kijko, A. (2004). Estimation of the maximum earthquake magnitude, mmax, Pure and Applied Geophysics, 161, 1655-1681.

[9] Kumar Pallav, S T G Raghukanth and Konjengbam Darunkumar Singh (2012), Probabilistic seismic hazard estimation of Manipur, India.

[10] S. T. G. Raghukanth and B. Kavitha (2014), Ground Motion Relations for Active Regions in India

[11] Stepp, J.C. (1972). "Analysis of Completeness of the Earthquake Sample in the Puget Sound Area and Its Effect on Statistical Estimates of Earthquake Hazard", Proceedings of the International

[12] Conference on Microzonation, Seattle, U.S.A.,Vol. 2,pp. 897-919

[13] USGS website (http://neic.usgs.gov/)

[14] RaghuKanth, S. T. G., (2008), Modeling and synthesis of strong ground motion, Journal Of Earth System Science, 117, 683-705,

[15] Report of National Disater Management Authority Govt. Of India, on "Development Of Probabilistic Seismic Hazard Map Of India" 28th August 2008 (vide No. 37/2008/PMU).
[16] . Das, S., Gupta, I.D. and Gupta, V.K. (2006), A probabilistic seismic hazard analysis of Northeast India, Earthquake Spectra, 22(1):1-27.

[17] Gupta, I.D. (2006). Delineation of probable seismic sources in India and neighbourhood by a comprehensive analysis of seismotectonic characteristics of the region, Soil Dynamics and Earthquake Engineering, 26,766-790.

[18] IBC. (2003). International Building Code. International Code Council.

[19] IS 1893-2002 (2002). Criteria for earthquake resistant design of structures: Part 1 - General provisions and buildings, Bureau of Indian Standards, BIS, New Delhi.

[20] Iyengar, R.N, Sharma, D, and Siddiqui, J.M. (1999), Earthquake history of India in medieval times, Indian Journal of history Science, 34 (3).

[21] Iyengar, R.N. (2000). Seismic status of Delhi Megacity, Current Science, 78, 568- 574.

[22] Kijko, A. and Graham, G. (1998), Parametric-historic procedure for probabilistic seismic hazard analysis: Part I - estimation of maximum regional magnitude mmax. Pure Appl. Geophys., 152:413-442.

[23] Kijko, A. and Graham, G. (1999), "Parametric-historic" procedure for probabilistic seismic hazard analysis, Part II: assessment of seismic hazard at specified site, Pure and Appl. Geophys., 154:1-22.

[24] Knopoff, L. and Kagan, Y. (1977), Analysis of the theory of extremes as applied to earthquake problems, J. Geophys. Res., 82:5647-5657.

[25] Mishra Devendra, Uniyal Aniruddha Dr., Uttar Pradesh State Disaster Management Plan For Earthquakes by U.P. Academy of Administration \& Management March, 2010

[26] Anbazhagan , Bajaj Ketan, Dutta1 Nairwita, Moustafa Sayed S R, Al-Arifi Nassir S N, (2017)" Region-specific deterministic and probabilistic seismic hazard analysis of Kanpur city” J. Earth Syst. Sci. (2017) 126: 12 c Indian Academy of Sciences DOI 10.1007/s12040-016-0779-6

[27] Interim Report On Geochemical Mapping September, 2019 In Toposheet No. 541/12 Covering Parts Of Sagar District Of Madhya Pradesh And Lalitpur District Of Uttar Pradesh, Geological Survey of India

[28] Correlation Of Different Tectonic Units Of Uttar Pradesh And Punjab Himalayas, Geological Survey Of India ,March, 1964,

[29] Bilham Roger,June 2004,"Earthquakes in India and the Himalaya: tectonics, geodesy and history", Annals Of Geophysics, Vol. 47, N. 2/3, April/June 2004.

[30] Shreyasvi C., Venkataramana Katta,2020 "Seismic Hazard Estimation for Southwest India" Springer Nature Singapore. 2020 , https://doi.org/10.1007/978-981-150890-5_18

[31]. Incorporated Research Institutions for Seismology, Earthquake browser, http //www.iris.edu/ hq/ (last accessed 26th October 2016.

[32] Indian Meteorological Department (IMD), www.imd.gov.in/, New Delhi, India (Through Personal 
communication) 41. International Seismological Centre, Online Bulletin, http //www.isc.ac.UK, Internatl. Seismol. Cent., Thatcham, United Kingdom, 2014 (last accessed on 31st October 2016)

[33] National Earthquake Information Center 2003 USA PDE reportingshttp //neic.usgs.gov/neis/ epic/ (last accessed on 28th November 2016).

[34] Mandal H. S., Shukla A. K., Khan P. K., And Mishra O. P.,2013, "A New Insight into Probabilistic Seismic Hazard Analysis for Central India" Pure Appl. Geophys. 170 (2013), 2139-2161 2013 DOI 10.1007/s00024-0130666-x.

[35] Kumar Aayush,March 2020, "Seismic Isolation And Energy Dissipating System For Earthquake Resistant Design" International Journal of Engineering Applied Sciences and Technology, 2020 Vol. 4, Issue 11, ISSN No. 2455-2143, Pg 151-159. 